\title{
Mica bearing pegmatites of Holenarasipura and Karighatta Schist belts of Western Dharwar Craton, Karnataka, India.
}

\author{
G. S. Somesha ${ }^{1 *}$ Govindaraju $^{2}$, M. Vinaya ${ }^{3}$ and S. Govindaiah ${ }^{4}$ \\ 1,2,3 Dept. of Applied Geology, Kuvempu University, Shankaraghatta, Shimoga, Karnataka, India \\ ${ }^{4}$ Department of Civil Engineering, Dayanandasagar Engineering College, Bangalore-560078, Karnataka, India \\ *Corresponding Author: somesh.g.shivu@gmail.com, Tel.: +91-9945881955
}

Available online at: www.isroset.org

Received: 29/Mar/2019, Accepted: 11/Apr/2019, Online: 30/Apr/2019

\begin{abstract}
Several pegmatite bodies of Precambrian age are located in and around the Holenarasipura and Karighatta schist belts of Hassan and Mandya districts respectively in the Dharwar Craton in Karnataka, These are ranging in size from few centimeters to more than 10 meters in width, with a maximum extension of about one kilometer. The pegmatites in the study area are of tabular, lensoidal and lenticular bodies, within the country rocks. Most of the pegmatites are found to be as concordant and few are discordant type of intrusions. Based on the mineralogical assemblage, the pegmatites of the study area are classified into simple and complex pegmatites. The characterization has been made for pegmatites on the basis of their petrographic, modal analysis, X-ray diffraction studies and also by field observation. The modal analysis has shown that the pegmatites fall mainly in the field of alkali feldspar granite, granite and granodiorite in QAP diagram with an indication of feldspar-rich composition followed by quartz, muscovite, biotite, garnet, zircon and apatite in decreasing abundance throughout the area.
\end{abstract}

Keywords- Pegmatites, Petrography, X-ray diffraction, Modal analysis, Holenarasipura and Karighatta

\section{INTRODUCTION}

In India the most extensive occurrence of pegmatites of Precambrian age are reported from the Bihar, Rajasthan and Nellore Mica belts [1], a few from central India, like the Koradi-Kolar sector of Nagpur District, Bastar-Koraput belt of Madhya Pradesh and Orissa which are important for their rare metal-bearing minerals [2], [3], [4], [5]. Apart from these, several pegmatite bodies hosted with a considerable amount of economically viable minerals that are rich in rare metals and micas were reported in the Holenarasipura and Karighatta Schist belt, which principally forms the part of Western Dharwar Craton of Karnataka [6], [7], [8]. The pegmatites of these belts are confined to a small area in metamorphic terrains and generally few of them are associated with that of the granitic rocks. Because of all these characteristic features, the pegmatites of the study area have gained much attention on their origin and occurrence. This made the researcher carry out their work on it and the present paper outlines about the field characteristics of pegmatites with their hosts, where the textural and structural evidence provides necessary information about the magmatic origin and influx of pegmatite fluids within the fractures and weaker planes in the host rocks. Along with this, the petrography and X-ray diffraction studies provide additional details on the mineral assemblages and mineral phases which helps in classifying pegmatite rocks. The study area occupies roughly about $400 \mathrm{sq} \mathrm{km}$ and it forms the part of Survey of India toposheets No. 57D 1/2/5/6/10/11/14 and 15 respectively. Here, an attempt has been made to evaluate the nature of pegmatite bodies by a multidisciplinary study with respect to their petrography, mineralogy and field characteristics.

\section{GeOlogical SETTING}

The marginal contacts of Holenarasipura schist belt with Peninsular gneisses show extensive feldspathisation and emplacement of both zoned and unzoned of pegmatites of variable dimensions. The trend of pegmatites, in general, is $\mathrm{N}-\mathrm{S}$, a few are also showing E-W trend. The pegmatites are zoned with well-marked, but asymmetrically developed, quartz core of variable thickness and continuity [9]. In Karighatta schist belt it is inferred that this schist belt represents a synclinal portion with major fold axis running along an $\mathrm{N} 15^{\circ} \mathrm{E}-\mathrm{S} 15^{\circ} \mathrm{W}$, direction. The chief rock types exposed in this area as found in Marlagalla, Karigatta and its neighborhood are quartzites, quartz-mica-schists, fuchsite quartzite, kyanite-sillimanite-garnet schist, amphibolites, felsites and crystalline limestone. Near Marlagalla and Allapatna villages $\mathrm{Nb}-\mathrm{Ta}$ bearing pegmatites are located almost near the southern tip of Yadiyur-Karigatta schist band of the Nagamangala schist belt, on the eastern margin of 
Karigatta hill [10]. The geological map of the study area along with sample locations is shown in Figure 1A and 1B.

\section{FIELD CHARACTERISTICS OF PEGMATITES}

\section{A. Pegmatites associated with foliated rocks}

a. Quartz- mica schist and quartzites: Mica-schist and quartzites are the most important rock type in the study area with huge emplacement of pegmatite bodies in it. These rocks are marked with well-developed schistosity, along with multiple sets of joints. At places of entrapment, this schist gets interbedded with quartzite bands. It is more evident in the field that most of the quartzite is not conditionally favorable for the emplacement of pegmatite.

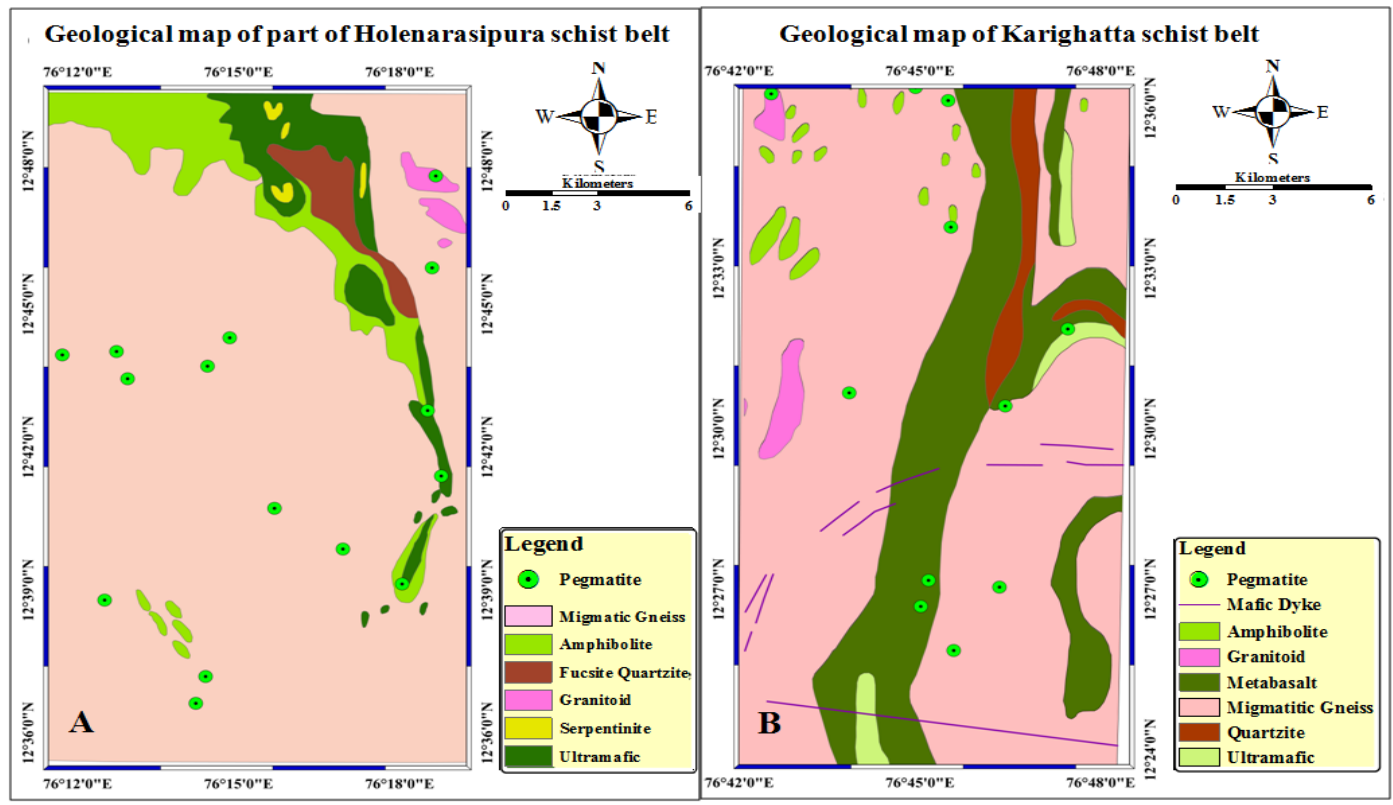

Figure 1: Geological map of the study area with pegmatite sample locations

However, most of the concordant pegmatite intrusions in the area are observed along with the contact of mica-schist and quartzite (Fig. 2F). It is quite natural that the foliations in the schists are not because of the contact effect made by pegmatite intrusion. Indeed, these foliations are recognized mainly of regional metamorphism which is previously occurred than before the pegmatite intrusions.

b. Amphibolites: Amphibolites are the predominant rock types which occur as bands and mounds associated with schists, quartzites and granitic gneisses in the study area. These amphibolites are emplaced by many pegmatitic bodies. These pegmatites cut across and also occur within the planes of schistosity of amphibolites. With few irregularities, most of the pegmatite bodies show sheet-like character and lie more or less parallel to the schist. Depending on the angle of inclination of foliation the pegmatite exhibits a dike or sill like form. Another characteristic feature of emplacement of pegmatite bodies in the area is their tendency to pinch and swell usually along with their trending direction (e.g. pegmatites emplaced near Allapatna and Maralagala area).
The contact between the pegmatite and amphibolites appear to be very sharp in the area (Fig. 2A).

c. Granitic Gneiss: Granitic gneisses are projected significantly and have limited aerial extent in the study area by the close association with amphibolites, schists and pegmatites (Fig. 2C). However, the gneisses that are emplaced by the pegmatites are probably of primary or flow foliates and generally has shades of pinkish white to reddish brown colour, and this is due to the presence of rich $\mathrm{K}$ -

feldspar (Fig 2B). In the vicinity of the gneisses the associated pegmatite cuts across their foliation, Whereas in the south of Byadarahalli village, some of the pegmatites seen slightly parallel to the folia, suggesting a slight flowing movement in the host rock at the time of pegmatite intrusions (Fig 2D \& 2E). The field evidence indicates that the pegmatite bodies associated with the gneisses are probably intrusions under high pressure of a less viscous into a more viscous magma. 
B. Pegmatites associated with massive granites: The granites are the most significant rock present in the area with considerable emplacement of pegmatite in them. The granites and associated pegmatites are the youngest known rocks occurring in remarkable abundance within the area [11]. The relationships that are exhibited between the pegmatite and the granite in the study area reflect much information on their pre-existence. The field observations reveal that the mineral composition between the granites and the pegmatite are quite similar. However, there is a variation in relationships existing between the two rocks, being characterized by the relations spot some light on illustrating that most of the pegmatites are distinctly intrusive to the surrounding rocks.

C. Size and Shape: The pegmatites show wide variation in size and shape. Most of the pegmatites are of tabular, sheets, veins, lensoidal, lenticular bodies and few others as branching and irregular within the country rocks, which irregularly disappearing under the soil cover. The size of the pegmatite bodies is ranging from a few centimeters to about $>10$ meters in width, with a maximum extension of about one kilometer. The size and shape of pegmatites bodies are structurally under great control with the rock into which they have been emplaced.

D. Wall Rock Alteration: The contact between the host rock and the pegmatites are sharp and well defined, but in few places, segregated by a thin zone of wall rock alteration. The alteration not only involves recrystallization of mica and silicification of wall rocks, but it also gives rise to the development of new minerals like muscovite, epidote, tourmaline and garnet by the pegmatitic fluids. The nature and degree of wall rock alteration mainly based on the mineralogical composition of wall rock and the mode of the pegmatite emplacement. The alteration is observed frequently in the concordant pegmatites which are emplaced in foliated rocks.

E. Structural Classification: Generally, the classifications of pegmatites are primarily done on the basis of their form, size, and relationship with the country rock, texture and internal structure [12], petrochemical composition [13] and mode of development [14], [15]. With reference to the structural relationship with the host rocks, the pegmatites of Holenarasipura and Karighatta schist belts are broadly distinguished as concordant and discordant types.

a. Concordant Pegmatites: Majority of the pegmatite bodies in the study area are essentially concordant with the general strike NE-SW in Karighatta and N-S \& E-W in Holenarasipura and dip of the associated rock (mica-schist and amphibolite). At many places, the tabular sheets of pegmatites are emplaced concordantly within the planes of schistosity of amphibolites to form banded gneiss (Fig. 2D, $2 \mathrm{G} \& 2 \mathrm{H}$ ). Lenticular pegmatites are broader but gradually pinch out either at one end or at both the ends. saline minerals and grading gradually into each other in the most complete manner. These relations shows that the pegmatites are not precisely of the same period and also, there is no any indication seen within or around the study area of very extensive divergence in the age of different pegmatites or granites. The field exposure also shows the broad contemporaneity of granite and pegmatite. In such condition, there may be no doubt that, the crystallization of both rocks are resulting from the same magma, and if look upon the pegmatitic masses, they are merely because of segregation within the granites. Though, the geologic b. Discordant Pegmatites: Although in the study area the discordant type of pegmatite bodies seems less available compared to concordant types. These types of intrusions follow the foliation of the pre-existing host rocks, where it predominantly tracks the joint planes that cut across the bedding and foliation with a sharp contact (Fig 2B). Such pegmatites at times show branching pattern (exposure near NE of Kallahalli village in Holenarasipura taluk) with irregular margins.

\section{PETROGRAPHY}

Based on the detailed field observation and by megascopic studies, the pegmatite samples of representative varieties from the different locations in the study area with related to the host rocks were selected and more than 30 thin sections were prepared for petrographic studies. The pegmatite deposits in all parts of the study area show great similarity in their principal minerals and exhibiting notable differences in their minor constituents. The mineral composition of the pegmatites from both the areas is primarily rich in feldspars, whereas the potash-rich feldspar conspicuously occurs in Karighatta schist belt and conversely soda rich feldspar in Holenarasipura schist belt followed by quartz, muscovite, biotite, garnet, zircon and apatite in decreasing abundance.

In thin sections, quartz shows wavy extinction and anhedral which is generally interstitial as a late-forming mineral, especially to the plagioclase and to a lesser extent to the $\mathrm{K}$ feldspar. Quartz occurs as granophyric and as myrmekitic intergrowths in small amount in the form of blebs and vermicules, it is probably released during the replacement of $\mathrm{K}$-feldspar by the plugs of sodic plagioclase. It also occurs as small round crystals at the margins of the plagioclase.

$\mathrm{K}$ - feldspar show medium grained, subhedral grains exhibits cross-hatched twinning with well perthitic textures (Fig 3A) and are characterized by cloudy, patchy and extensive coarsening nature due to feldspar-fluid interaction [16], [17]. At few places, minute mica flakes are also observable along the margins of perthite as post-magmatic phases due to accumulation of residual fluid. The microperthitic K-feldspar also showing thin films of albite transgressing microcline and rarely myrmekitic intergrowth has been observed along the margins of some grains of K-feldspar. 
Plagioclase usually occurs as coarse subhedral aggregates and as discrete phenocrysts in the granular aggregates of quartz. Sericitization of plagioclase are also observed as a minor phase in thin section and exolution of plagioclase lamella making perthitic texture is also observed.

The muscovite embedded mostly in aggregate of quartz and plagioclase as books and flakes which are often observed intergrowth with plates of quartz. These muscovite flakes are fresh and are characterized by peacock colour (Fig 3D \& $3 \mathrm{G})$. However, the development of kink bands in muscovite is also observed, which are formed by replacing the plagioclase (Fig 3E).

The biotite occurs as thick anhedral to subhedral flakes with ragged fractures and mostly concentrated within quartzofeldspathic layers, which are aligned parallel to the foliation with one set of perfect cleavages. In thin section, few biotite foliations enveloping the porphyroclasts of $\mathrm{K}$ - feldspar are observed (Fig 3F).

Garnets occur commonly as euhedral crystals with welldefined boundaries, associated with quartz and plagioclase of which quartz is likely intergrown (Fig 3B). Zircon rarely occurs as euhedral and prismatic crystals scattered throughout the rock (Fig 3C).

On the basis of mineralogical variations, the pegmatite of the study area represents both simple and complex types. Simple pegmatites are those which are unzoned and consisting of quartz, feldspar, biotite and apatite as accessories. Though the complex pegmatites are zoned and have a similar mineralogical composition as the simple type in addition to muscovite and garnet in it. Graphic intergrowth of quartz and feldspar are also characteristics of complex pegmatites. 

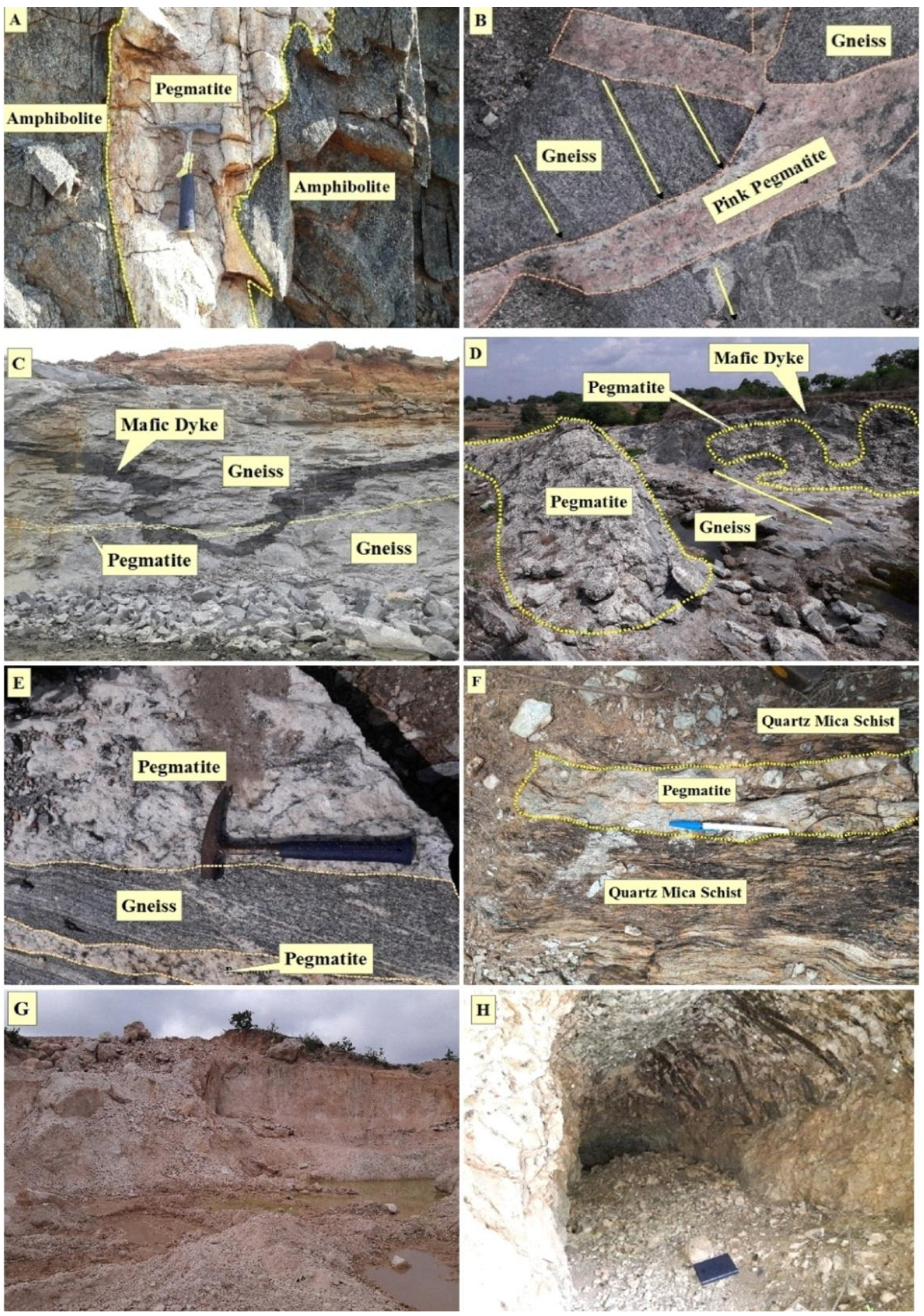

Figure 2. Field photographs A) Sharp contacted pegmatite body associated within steeply dipped amphibolite near Yenneholeranganabetta. (B) The pink pegmatite body cutting across the foliation indicating its discordant nature. (C) The pegmatite vein intruded both in gneiss and dyke rock near Maralagalla. (D) The emplacement of concordant pegmatite (E) Pegmatite emplacement slightly parallel to the folia, suggesting a slight flowing movement in the host rock. (F) The pegmatite intrusions observed along the foliation of mica-schist near Gunjur (G) Feldspar rich pegmatite mine near south of Mundur and (H) Muscovite rich pegmatite mine near east of Mundur. 

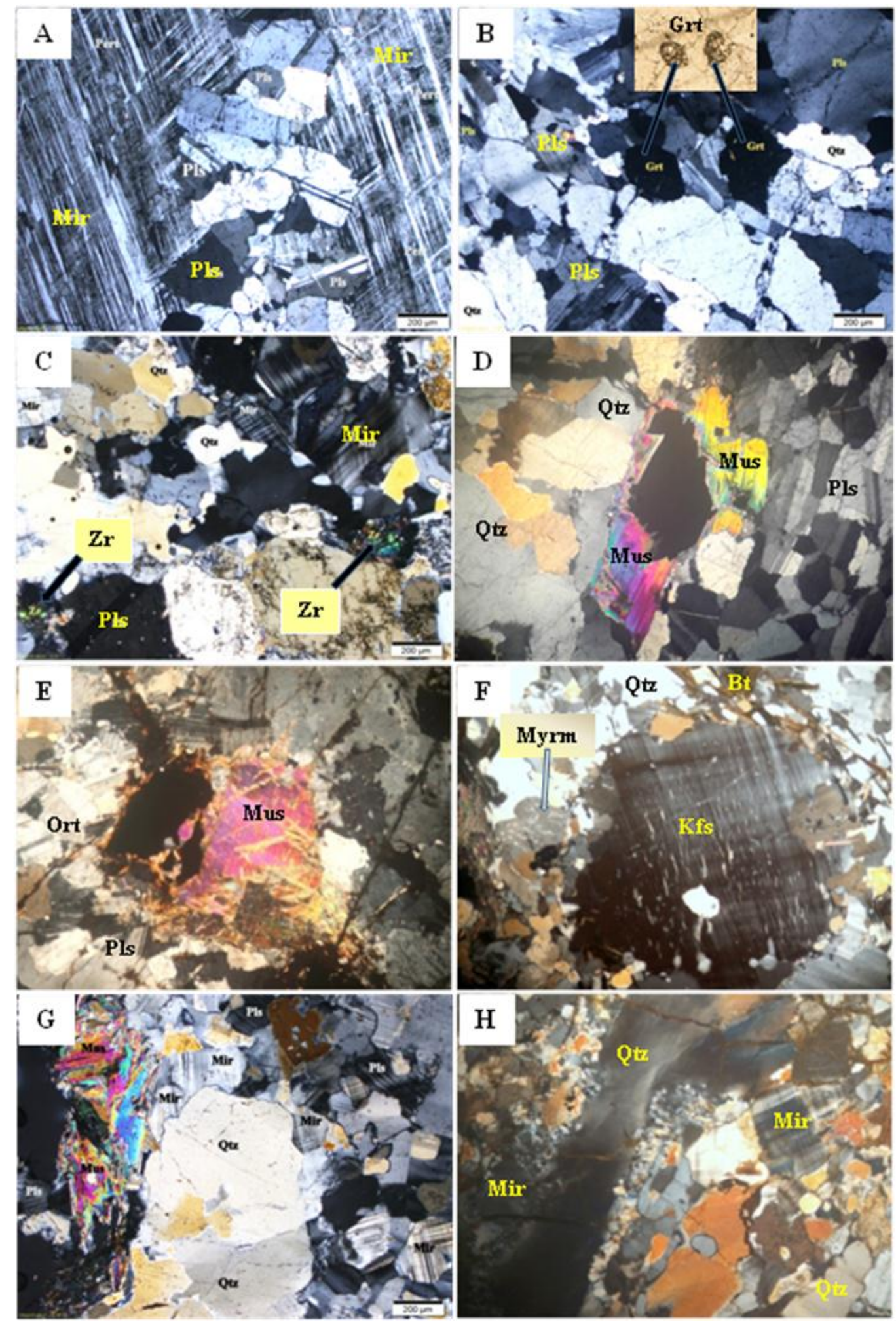

Figure 3: Photomicrographs with (A) Laths of plagioclase with albitic tints found as inclusions within a microcline grain. (B) The well developed euhedral garnet crystals surrounded by quartz and plagioclase. (C) Porphyroblasts of microcline with cross hatched twinning and anhedral to subhedral quartz are disseminated in quartzofelspathic groundmass with few intrusion of zircon in it. (D)The fresh muscovite flakes with peacock colour embedded within quartz and plagioclase. (E) Replacement of plagioclase by muscovite with development of Kink bands in it. (F) K-feldspar porphyroclast in course grained pegmatite 
showing tartan twinning with relative straight grain boundaries in their matrix. (G) Muscovite rich zones in pegmatites along with serrated quartz and microcline grains. $(\mathrm{H})$ Replacement relationship of microcline grains showing embayed grain boundaries wherequartz is seen to replace microcline.

\section{MODAL ANALYSIS}

The Detailed petrological studies were carried out by using an Olympus microscope with swift Point Counter and ImageJ software at the Department of Applied Geology, Kuvempu University. The pegmatites of study area occupy a central area of the QAP diagram. The modal composition of (volume $\%$ ) of selected pegmatites are shown (Table-1), which indicates that the modal composition (volume \%) of minerals ranging from quartz 23.34 to 58.37 , K-feldspar 1.4 to 71.31 , plagioclase 3.25 to 64.1 , biotite 0 to 2.38 , muscovite 0 to 13.83 , garnet 0 to 1.25 , zircon 0 to 0.65 , epidote 0 to 0.1 .34 and apatite from 0 to 0.56 . After plotting on QAP diagram the pegmatites falls in the field of alkali-feldspar granite, granite, quartz-rich granitoid, granitoid and Tonalitetrondhjemite fields[18] (see Fig. 4).

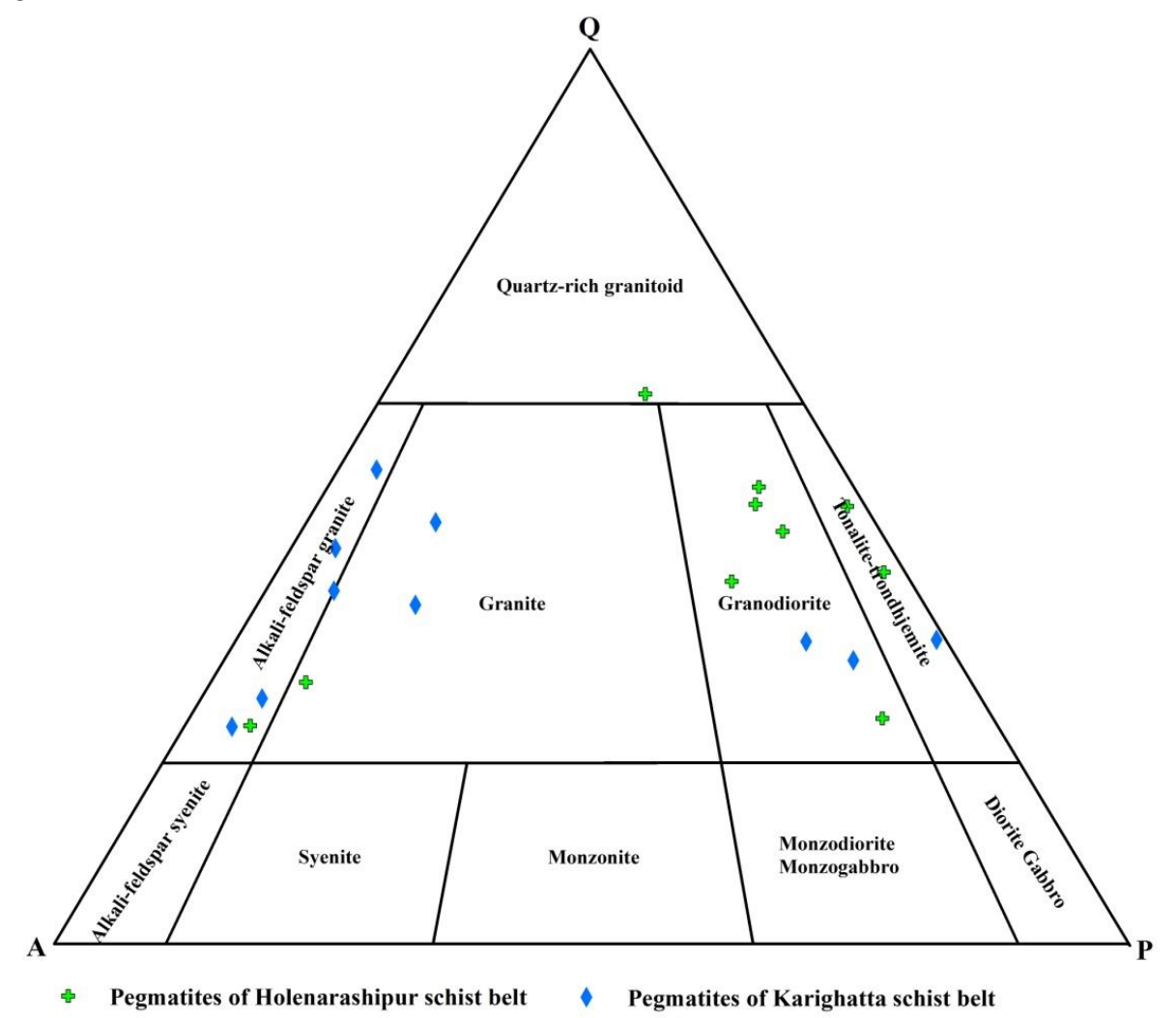

Figure 4: Quartz - Alkali feldspar - Plagioclase diagram (after Streckeisen, 1973).

Table 1: Modal analysis data of pegmatites of Holenarasipura and Karighatta schist belts (Values in \%).

\begin{tabular}{|c|c|c|c|c|c|c|c|c|c|c|}
\hline Sample No & Quartz & K-feldspar & Plagioclase & Epidote & Muscovite & Biotite & Apatite & Zircon & Garnet & Total \\
\hline HSB2 & 39.3 & 16.8 & 40.9 & 0 & 1.89 & 1.11 & 0 & 0 & 0 & 100 \\
\hline HSB4 & 27.3 & 58.58 & 8.12 & 1.2 & 3.78 & 1.02 & 0 & 0 & 0 & 100 \\
\hline HSB21 & 46.6 & 10.3 & 38.2 & 0 & 3.41 & 0.93 & 0.56 & 0 & 0 & 100 \\
\hline HSB31 & 41.82 & 8.61 & 39.78 & 0 & 7.41 & 2.38 & 0 & 0 & 0 & 100 \\
\hline HSB41 & 38.8 & 5.1 & 53.1 & 0 & 2.57 & & 0.43 & 0 & 0 & 100 \\
\hline HSB46 & 58.37 & 13.89 & 24.87 & 0 & 0.94 & 1.34 & & 0.59 & 0 & 100 \\
\hline HSB59 & 41.58 & 1.85 & 41.65 & 0 & 13.83 & 0 & 0.44 & 0.65 & 0 & 100 \\
\hline HSB61 & 24.23 & 68.46 & 5.48 & 0 & 0 & 0 & 0 & 0.58 & 1.25 & 100 \\
\hline HSB62 & 25.2 & 10.7 & 64.1 & 0 & 0 & 0 & 0 & 0 & 0 & 100 \\
\hline HSB69 & 48.73 & 9.1 & 37.97 & 0 & 3.23 & 0.97 & 0 & 0 & 0 & 100 \\
\hline KSB1 & 35.2 & 44.2 & 13.1 & 0 & 7.5 & 0 & 0 & 0 & 0 & 100 \\
\hline KSB6 & 27.24 & 66.32 & 5.2 & 0 & 1.24 & 0 & 0 & 0 & 0 & 100 \\
\hline KSB7 & 35.6 & 48.12 & 7.28 & 1.34 & 6.18 & 1.48 & 0 & 0 & 0 & 100 \\
\hline KSB18 & 31.33 & 12.34 & 52.18 & 0 & 4.15 & 0 & 0 & 0 & 0 & 100 \\
\hline KSB33 & 43.8 & 38.56 & 10.64 & 0 & 5.18 & 1.04 & 0 & 0 & 0.78 & 100 \\
\hline KSB38 & 49.67 & 41.81 & 3.25 & 0 & 3.29 & 1.98 & 0 & 0 & 0 & 100 \\
\hline
\end{tabular}




\begin{tabular}{|l|c|c|c|c|c|c|c|c|c|c|}
\hline KSB42 & 41.83 & 49.28 & 3.89 & 0 & 4.2 & 0.8 & 0 & 0 & 0 & 100 \\
\hline KSB48 & 23.34 & 71.31 & 4.45 & 0.9 & 0 & 0 & 0 & 0 & 0 & 100 \\
\hline KSB52 & 29.4 & 1.4 & 55.2 & 0 & 13.26 & 0.74 & 0 & 0 & 0 & 100 \\
\hline KSB55 & 29.78 & 9.77 & 54.63 & 0 & 4.58 & 0 & 0 & 0 & 1.24 & 100 \\
\hline
\end{tabular}

\section{X-RAY DIFFRACTION STUDIES}

The X-ray Diffraction studies were carried out for 14 feldspar-rich pegmatite samples and the diffraction patterns of the pegmatites were obtained by using XPERT-PRO X-ray Diffractometer system operated at $40 \mathrm{~mA}$ and $45 \mathrm{kV}$ with $\mathrm{Cu}$ $(\mathrm{K} \alpha)$ radiation. The sample was scanned between $4^{\circ}$ to $43^{\circ}, 2-$ Theta $(\theta)$ range with $1^{\circ} 2$ thetas $(\theta)$ per minute scanning speed. The peak angles and spacings obtained were compared with the published data from the American Mineralogist crystal structure database [19], [20]. The diffraction patterns of the feldspar-rich pegmatite from the study area are given in Fig. 5 and interplanar spacings ('d') and 'hkl' values along with mineral names are given in Table 2. The X-ray diffraction (XRD) studies have revealed that the pegmatites are predominantly rich in sodic feldspar in the Holenarasipura schist belt and with high potash-rich feldspar in Karighatta schist belt showing remarkable albite and microcline mineral phases respectively.

\section{CONCLUSION}

The pegmatites of the study area show simple to complex mineral assemblage (quartz, feldspar, mica, garnet, apatite, etc.). Most of the pegmatite bodies are emplaced within the foliated rocks (mica-schist, gneisses and amphibolites) along with bedding, fracture/ joint, fault planes and in the contact of two different host rocks. However, pinching and swelling structures in pegmatite are noticed locally in the amphibolites. The pegmatites emplacement indicates the smooth flowage of their magma through their available foliation planes in the host rocks. The pegmatites occur mostly as groups, with distinction in their size and shape such as tabular, lenticular and vein like bodies, which are irregularly disappearing under the soil cover.

On the basis of mineralogical variations, the pegmatites of the study area are classified as simple and complex types. The field evidence reveals about the two distinct generations of muscovite mica. The earlier books of muscovites are observed in Doddakadanur and Kabbur villages, whereas later formed disseminated flakes of mica are observed in the groundmass of little coarser quartz near Mundur village of Holenarasipura schist belt and entire Karightta schist belt.

The mineralogical similarity and association with granites of pegmatites of both in Holenarasipura and Karighatta schist belt indicate that they are genetically related. X-ray diffraction studies and modal analyses reveal that the mineral composition of the pegmatites from both the area is primarily rich in feldspars, where the potash-rich feldspar conspicuously occurs in Karighatta schist belt and conversely soda-rich feldspar in Holenarasipura schist belt.

Table 2 - XRD data of feldspar-rich pegmatites compared with published values.

\begin{tabular}{|c|c|c|c|c|c|c|c|c|c|c|c|c|c|}
\hline \multicolumn{7}{|c|}{ Albite } & \multicolumn{7}{|c|}{ Microcline } \\
\hline \multicolumn{4}{|c|}{ Observed data values } & \multirow{2}{*}{\multicolumn{3}{|c|}{$\begin{array}{c}\text { Compared data values } \\
\text { Harlow (1982) }\end{array}$}} & \multicolumn{4}{|c|}{ Observed data values } & \multirow{2}{*}{\multicolumn{3}{|c|}{$\begin{array}{c}\text { Compared data values } \\
\text { Blasi et al (1987) }\end{array}$}} \\
\hline \multicolumn{2}{|c|}{ HSB 45} & \multicolumn{2}{|c|}{ HSB 46} & & & & \multicolumn{2}{|c|}{ KSB 1} & \multicolumn{2}{|c|}{ KSB 7} & & & \\
\hline$d\left(A^{0}\right)$ & $\left(I / I_{0}\right)$ & $d\left(A^{0}\right)$ & $\left(I / I_{0}\right)$ & $d\left(A^{0}\right)$ & $\left(I / I_{0}\right)$ & $\overline{h k l}$ & $d\left(A^{0}\right)$ & $\left(I / I_{0}\right)$ & $d\left(A^{0}\right)$ & $\left(I / I_{0}\right)$ & $d\left(A^{0}\right)$ & $\left(I / I_{0}\right)$ & $\overline{h k l}$ \\
\hline 6.36259 & 11.03 & 6.35009 & 8.29 & 6.3762 & 5.06 & 001 & 6.47073 & 4.73 & 6.49374 & 5.13 & 6.4794 & 4.86 & 001 \\
\hline 3.49999 & 0.83 & 3.49595 & 1.17 & 3.5249 & 1.05 & -131 & 3.8567 & 11.34 & 3.83485 & 2.58 & 3.8514 & 7.68 & 200 \\
\hline 3.1861 & 100 & 3.18331 & 100 & 3.1881 & 100 & 002 & 3.65238 & 5.24 & 3.65741 & 1.09 & 3.6427 & 15.51 & $-1-31$ \\
\hline 3.18576 & 51.72 & 3.18267 & 48.79 & 3.1575 & 40.66 & 220 & 3.59659 & 1.82 & 3.60606 & 0.38 & 3.5899 & 12.81 & $-2-21$ \\
\hline 2.9254 & 3.07 & 2.92857 & 1.91 & 2.9233 & 13.18 & $0-22$ & 3.50242 & 5.23 & 3.48955 & 3.75 & 3.4807 & 2.31 & -221 \\
\hline 2.85407 & 1.39 & 2.85264 & 0.52 & 2.8456 & 1.73 & -222 & 3.24225 & 100 & 3.24626 & 100 & 3.2481 & 100 & 002 \\
\hline 2.38759 & 0.24 & 2.46782 & 0.16 & 2.3915 & 4.57 & 240 & 3.24129 & 58.25 & 3.24579 & 55.64 & 3.2384 & 41.58 & 040 \\
\hline 2.31656 & 0.42 & 2.38894 & 0.33 & 2.3217 & 1.1 & $-1-13$ & 2.95323 & 5.67 & 2.95556 & 2.55 & 2.958 & 6.93 & $-2-22$ \\
\hline 2.27285 & 0.25 & 2.31364 & 0.09 & 2.2795 & 2.95 & -113 & 2.88878 & 23.18 & 2.89228 & 1.12 & 2.8883 & 5.8 & $0-22$ \\
\hline 2.12547 & 2.23 & 2.27289 & 1.54 & 2.1219 & 5.7 & 151 & 2.61609 & 2.47 & 2.75641 & 0.66 & 2.6181 & 10.96 & $-3-12$ \\
\hline 1.97862 & 0.99 & 2.13051 & 0.96 & 1.9734 & 1.2 & 311 & 2.42966 & 1.79 & 2.42955 & 0.71 & 2.4344 & 2.18 & -240 \\
\hline 1.84975 & 0.54 & 1.9729 & 1.31 & 1.8498 & 1.01 & $3-31$ & 2.33036 & 1.72 & 2.33206 & 0.69 & 2.329 & 3.7 & $-1-13$ \\
\hline
\end{tabular}




\begin{tabular}{|cc|cc|ccc|cc|cc|ccc|}
1.80042 & 1.27 & 1.82431 & 0.53 & 1.8142 & 2.85 & $-2-62$ & 2.1566 & 3.61 & 2.15852 & 1.58 & 2.1528 & 10.26 & 241 \\
1.80052 & 0.68 & 1.79963 & 0.48 & 1.7993 & 2.19 & -170 & 1.57125 & 1.95 & 1.57318 & 0.51 & 1.5739 & 3.39 & 024 \\
1.78273 & 0.77 & 1.79571 & 0.29 & 1.7827 & 1.07 & -420 & 1.47351 & 0.8 & 1.47333 & 0.21 & 1.4739 & 3.02 & -514 \\
1.63796 & 0.29 & - & - & 1.6318 & 1.15 & $-3-34$ & 1.45343 & 1.8 & 1.45405 & 0.76 & 1.4544 & 3.39 & 114 \\
1.59489 & 0.7 & - & - & 1.6121 & 2.87 & 080 & 1.40956 & 0.64 & 1.41098 & 0.36 & 1.4116 & 1 & -460 \\
1.57152 & 0.51 & 1.59395 & 0.55 & 1.5738 & 2.82 & $-4-24$ & 1.31697 & 1.33 & 1.3182 & 0.19 & 1.3179 & 1.32 & 531 \\
\hline
\end{tabular}
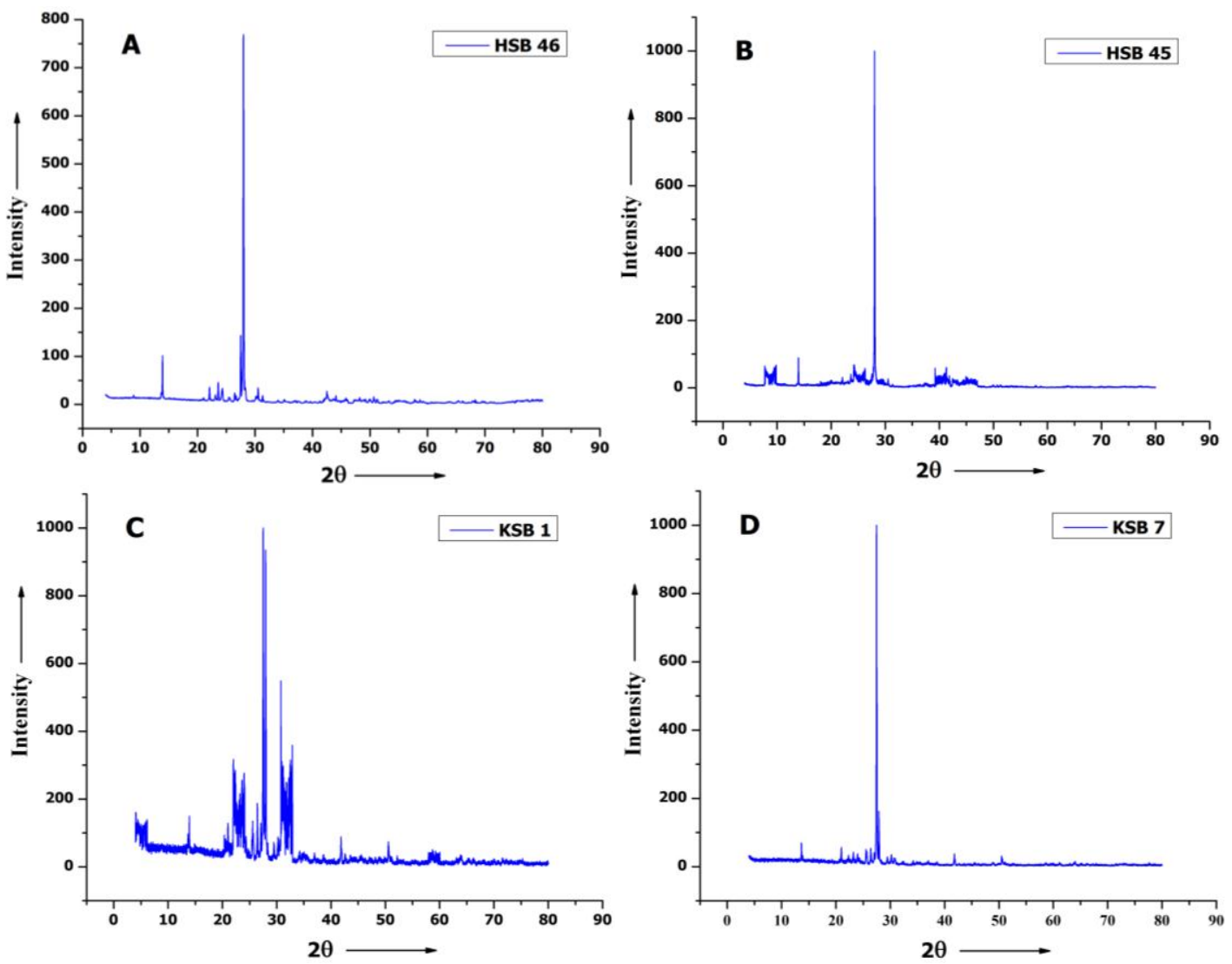

Figure 5: X-ray diffractogram of feldspar-rich pegmatite containing (A) \& (B) Albite, (C) \& (D) Microcline.

\section{ACKNOWLEDGMENTS}

Authors would like to the thank Chairman, Co-ordinator UGC -SAP (III) of Department of Applied Geology, Kuvempu University for extending support and Director and his staff of Wadia Institute of Himalayan Geology, Dehradun for providing an opportunity to carryout XRD analyses.

\section{REFERENCES}

[1] K.L. Bhola, "Atomic Mineral Deposits in Bihar Mica-Belt", Proc. Indian Nat. Sci. Acad. 37 A, No. 2, pp. 145-168, 1971.

[2] C. Ramaswamy, M.L. Deshpandc, K.S. Murthy, H.P. Jaiswar, R.S. Jcsani, "Tin-bearing pegmatites of Baslar, M.P”, Geol. Surv. India, Spl. Pub. No. 3, pp.185-189, 1976.
[3] V.J.S. Lamba \& V.K. Khanna, "Characteristic features of tinbearing rare metal pegmatites of Konla Tahsil, Bastar Dist, M.P", Bull. Indian Geol. Assoc, Vol.14, No.2, pp.151-154, 1981.

[4] P.V.R. Babu, "Tin and rare metal pegmatites of the Bastar Koraput pegmatite Belt, Madhya Pradesh and Orissa", India. Jour. Geol. Soc. India,Vol .42, pp.80-90, 1993.

[5] L.G. Gwalani, V.P. Dalal, S. Soledad Fernandez, B.P. Mulai, Shireen Parveen and B.V. Shastry, "Granitic pegmatites of Koradi-Kolar sector, Nagpur District, Central India: Field, Petrographic and Mineralogical features", Brazilian Journal of Geology, Vol.29, No.1, pp. 99-104, 1999.

[6] D.C. Banerjee, N. Ranganath, P.B. Maithani and K.M.V. Jayaram, "Rare metal bearing pegmatites in parts of southern Karnataka", India. Jour. Geol. Soc. India, Vol.30, pp. 507-513, 1987.

[7] D.C. Banerjee, K.V.G. Krishna, G.V.G.K. Murthy, S.K. Srivastava, R.P. Sinha, "Occurrence of spodumene in the rare 
metal bearing pegmatites of Marlagalla-Allapatna area, Mandya district, Karnataka, India", Jour. Geol. Soc. India, Vol.44, pp.127139, 1994.

[8] Chanchal Sarbajna, P. Krishnamurthy, "The fertile granite at Allapatna, Mandya district, Karnatka: A possible parent to Rare metal pegmatites of southern Karnataka", Jour. Geol. Soc. India, Vol. 46, pp. 95-98, 1996.

[9] P.B. Maithani, "Rare-metal pegmatite bodies with recoverable columbite-tantalite from the Arehalli area, Hassan dist, Karnataka". Explor. Res. Atomic Minerals, Vol.20, pp.1-11, 2010.

[10] Chanchal Sarbajna, P. Krishnamurthy, "Raremetal pegmatites of Marlagalla-Allpatna area, Mandya district, Karnataka: Some aspects on pegmatite zonation and geochemistry of pegmatitic minerals", Jour. of Atomic Mineral Science, Vol.02, pp.29-43, 1994.

[11] Chanchal Sarbajna, U. K. Pandey, P. Krishnamurthy, "Geochemistry and Petrogenesis of 2.8 Ga Old Rare Metal Bearing Fertile Granite at Allapatna, Mandya District, Karnataka”. Jour. Geol. Soc. India, Vol.91, pp.67-75, 2018.

[12] A.K. Datta, "Internal Structure, Petrology and Mineralogy of calcalkalinc pegmatites in parts of Rajasthan", Mem. Geol. Surv. India, Vol.110, pp.1-112, 1973.

[13] V.R. R.M. Babu, "Temperature of Formation of pegmatites of Nellore Mica Belt, A.P, India", Econ.Geol, Vol.64, pp.66-71, 1969.

[14] K. Soman, N. G. K. Nair, A. V. Druzhinin, "Chrysoberyl pegmatites of South Kerala and their metallogenic implications",
Journal of the Geological Society of India, Vol.27, No.5, pp. 411418, 1986.

[15] Y. Singh, D.S. Sharma, "Geology of Tantalitc pegmatite from Belangi, Surguja District, Madhya Pradesh, India”, Jour. Geol. Soc. India, Vol.49, pp.427-432, 1997.

[16] I. Parson, "Alkali feldspar and Fe-Tin oxide exsolution textures as indicators of the distribution and subsolidus effects of magmatic "water" in the Klokken layered syenite intrusion, South Greenland", Transactions Research Society, Edinburgh. Earth Science, Vol.71, pp.1-12, 1980.

[17] R. A. Yund, D. Ackermand, "Development of perthite microstructures in the Storm King granite, N.Y", Contributions to Mineralogy and Petrology, Vol.70, No.3, pp.273-280, 1979.

[18] A.L. Streckeisen, "Plutonic Rocks: Classification and Nomenclature Recommended by the I.U.G.S. Sub-Commission on the Systematic of Igneous Rocks", Geo, Times, Vol.18, pp.26-30, 1973.

[19] G E. Harlow, "The anorthoclase structures: The effects of temperature and composition", American Mineralogist, Vol.67, pp. 975-996, 1982.

[20] A. Blasi, C. De Pol Blasi, P.F. Zanazzi, "A re-examination of the Pellotsalo microcline: Mineralogical implications and genetic considerations", The Canadian Mineralogist, Vol.25, pp. 527-537, 1987. 